\title{
The Internationalization of Oil\&Gas Family Businesses
}

\author{
Giovanna Testa ${ }^{\mathrm{a}, 1}$ \\ ${ }^{a}$ Department of Management Studies and Quantitative Methods
}

\begin{abstract}
The internalization of family businesses- i.e. of the companies that implement it - can be stimulated by numerous reasons: one of these is linked to the target markets, not in terms of market development, but of resource to be used / exploited. What makes the oil companies distinguishing is that: they follow the territory and the exploitation of the underground resources, wherever they are in the world. In the Italian context, this characteristic of oilfield companies is very noticeable due to the scarcity of underground resources, which characterize our territory. We propose an empirical approach. It has been considered the case of a specific Italian Oil\&Gas family firm. The study consists of: a first part, in which an analysis of the main economic and managerial literature, both national and international, was made (on internationalization, SMEs and family businesses, industrial districts, oilfield environment); a second part, in which an empirical analysis was developed: interviews have been conducted with the owners and top management of the company, in order to study and analyze the firm development strategies.
\end{abstract}

Keywords. Family Business, oilfield, internationalization, oil district.

\section{Introduction}

The internationalization of companies has represented in recent years and still represents a fundamental strategy for all those companies with the wish and the need to broaden their economic horizons and their outlet markets. Being able to internationalize is not a common in all companies: this possibility and this "strength" are configured as the basic elements of the international corporation, which must have both the ability to face new and different markets and should have the "force" to deal with international competitors.

Until about twenty years ago, internationalization has been implemented as a strategy by large enterprises and multinational companies, which were and still are capable of dealing with complex and ever-changing environments, often conditioned and regulated by very different legislation.

In the Italian business context, this kind of development strategy has been less widespread: indeed, our business context is made up of both highly specialized small firms and small and medium-sized family businesses.

${ }^{1}$ Giovanna Testa, Department of Management Studies and Quantitative Methods, University of Naples 'Parthenope', Naples, Italy; E-mail: giovanna.testa@uniparthenope.it 
Furthermore, in many geographic areas, SMEs have joined together and created industrial districts. These districts, depending on the nature of the good produced, can take on different conformations: among the most widespread, we find the DIM, Marshallian manufacturing district [1], and the Markusenian district of the "Hub \& Spoke" type [2].

This work addresses the case of the internationalization of a SME's family business belonging to the Oil\&Gas sector [3]. The present work was performed starting from the study of the main theories in the field of internationalization, family businesses and SMEs. The case study considers the events and the international development of SMAPE Ltd, a company based in Abruzzo, in the province of Pescara, which has now expanded into several continents.

\section{Family Businesses}

SMEs tend to be associated with family businesses, even if it is not as common as it seems.

Many SMEs aren't familiar and many family businesses aren't SMEs! We can talk about Family Business (FB) when one or more family constitute a single economic and social identity with the company.

In the literature several theories and parameters define the FB [4-8]; the criteria are based on:

- objective criteria: are related to the role that the family plays in the ownership and management, as the percentage of ownership held, the right to vote, family members involved in the management and others;

- subjective criteria: concern qualitative variables, such as the degree of overlap between family and company matching values, the interdependence between the two systems, and so on.

Some authors [9] have identified three levels of family involvement in the company, thus giving them three different definitions.

Table 1. Definition of family business based on the degree of family involvement.

\begin{tabular}{|c|c|c|}
\hline Broad Definition & Narrow Definition & Media Definition \\
\hline $\begin{array}{l}\text { - Effective control over } \\
\text { strategic direction } \\
\text { - Intention to maintain the } \\
\text { property in the family }\end{array}$ & $\begin{array}{l}- \text { Founder/descendant manages } \\
\text { the company } \\
\text { - Legal control of the majority } \\
\text { of votes }\end{array}$ & $\begin{array}{l}\text { - More than one generation } \\
\text { - Family directly involved in } \\
\text { management and ownership } \\
\text { - More than one member of the } \\
\text { family with important } \\
\text { managerial responsibilities }\end{array}$ \\
\hline$\underset{\text { Direct family involvement }}{\nabla}$ & $\begin{array}{c}\boldsymbol{\nabla} \\
\begin{array}{c}\text { Average direct family } \\
\text { involvement }\end{array}\end{array}$ & $\begin{array}{l}\boldsymbol{\nabla} \\
\begin{array}{l}\text { High direct involvement of } \\
\text { the family }\end{array}\end{array}$ \\
\hline
\end{tabular}

Demattè and Corbetta [10] identify two types of family businesses:

- Family business in the strict sense, in which the family has high proprietary functions, managerial and entrepreneurial, corresponding to a high degree of concentration of ownership in the hands of one family;

- Extended family business, a company where the family has medium or low ownership, managerial and entrepreneurial functions, to which corresponds a medium or low degree of concentration of ownership in the hands of a single family.

Finally, the managerial company, although present in the chart, is not classified as a family business, because the family has no ownership, entrepreneurial and managerial functions and the degree of family control is zero. 
Subsequently, Corbetta [11] added a third variable to the model, and identifies the following three characteristics: a) ownership of capital; b) presence of family members on the board and in business management; c) staff size of the organization. So, four types of business have been identified, as shown in the table 2 .

Table 2. Types of family businesses.

\begin{tabular}{|c|c|c|c|}
\hline & Ownership model & $\begin{array}{l}\text { Presence of the family in } \\
\text { the BoD and in the } \\
\text { management bodies }\end{array}$ & $\begin{array}{c}\text { Size of the } \\
\text { personal } \\
\text { organization }\end{array}$ \\
\hline $\begin{array}{c}\text { Domestic Family } \\
\text { Businesses }\end{array}$ & $\begin{array}{l}\text { A single subject or a } \\
\text { small number of people }\end{array}$ & $\begin{array}{c}\text { Family board } \\
\text { Family management }\end{array}$ & Small \\
\hline $\begin{array}{c}\text { Traditional Family } \\
\text { Businesses }\end{array}$ & $\begin{array}{l}\text { A single subject or a } \\
\text { small number of people }\end{array}$ & $\begin{array}{c}\text { Family board } \\
\text { Family and non-family } \\
\text { management }\end{array}$ & $\begin{array}{c}\text { Small } \\
\text { Medium/Large }\end{array}$ \\
\hline $\begin{array}{c}\text { Extended Family } \\
\text { Businesses }\end{array}$ & $\begin{array}{c}\text { A larger number of } \\
\text { subjects }\end{array}$ & $\begin{array}{l}\text { Family and non-family } \\
\text { board } \\
\text { Family and non-family } \\
\text { management }\end{array}$ & $\begin{array}{l}\text { Medium } \\
\text { Large }\end{array}$ \\
\hline $\begin{array}{c}\text { Open Family } \\
\text { Businesses }\end{array}$ & $\begin{array}{l}\text { Individuals belonging } \\
\text { to the family and also } \\
\text { other members external } \\
\text { to it }\end{array}$ & $\begin{array}{l}\text { Family and non-family } \\
\text { board } \\
\text { Family and non-family } \\
\text { management }\end{array}$ & $\begin{array}{l}\text { Medium } \\
\text { Large }\end{array}$ \\
\hline
\end{tabular}

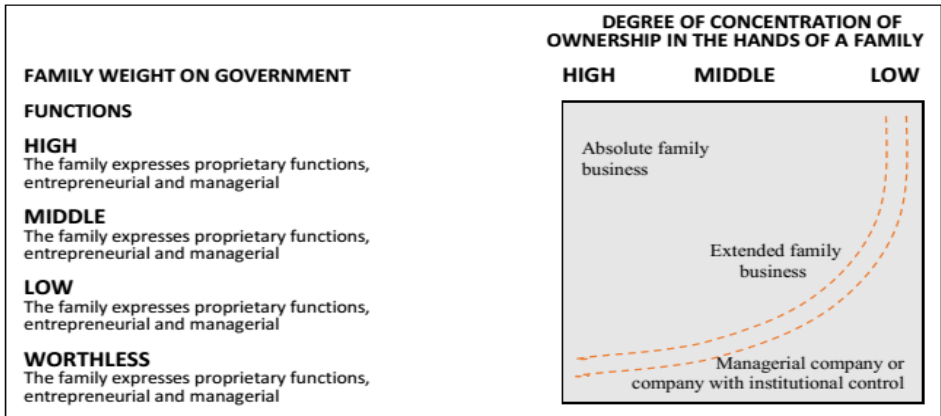

Figure 1. Classification of Family Businesses

These typologies of enterprise can be seen both in the descriptive and in evolutionary sense: in them, you can read an inversely proportional growth between the dimensional development of the company with a progressive and less commitment of the same family in the enterprise, which is in the direction and in the ownership.

\subsection{Industrial District}

The Industrial Districts (ID) are production systems which, since the early 1970s, have represented a much-studied area. In the Italian economic literature, the first to integrate Alfred Marshall's studies with the entrepreneurial reality of our country was Becattini [12]. The scholar defined the Districts as "socio-territorial entities characterized by the simultaneous active presence, in a limited territorial area, determined from a naturalistic and historical point of view, by the presence of a community of people and population of businesses" [13]. In these contexts, the socio-cultural elements are decisive for the achievement of the competitive advantage realized by SMEs operating in the same geographical area $[14,15]$. The local culture, therefore, becomes an element of cohesion, which allows individual actors to become part of the whole. The companies and the people who work there constitute the social environment of the district. With the evolution of business and economic studies, the industrial district has been classified according to different points of view: a) as an economic entity that is 
halfway between business and industry [16]; b) as a cognitive system [17-20]. Ann Markusen, in the 90s, gives her own classification of the Industrial Districts [21, 22].

\subsection{Hub-and-spokes ID}

With Markusen's theories, the districts no longer have the characteristics theorized by Marchall and Becattini, but become systems that represent and follow different managerial philosophies, assuming very dissimilar conformations.

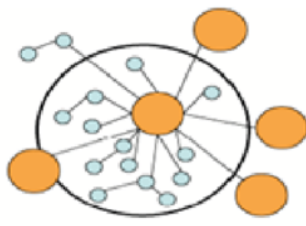

Figure 2. Hub and Spoke District.

In the Markusian districts it's possible to observe the presence of large companies, private and/or state-owned, which act as the fulcrum of business systems, in which local SMEs play the role of suppliers and sub-suppliers. The companies are linked by contractual systems that highlight the existence of asymmetries of power within the district. Large corporations exert and hold greater strength in inter-company relationships. The theorized district models are: a) Marchallian ID; b) hub \& spoke district; c) the "satellite platform"; d) "state anchored" cluster.

The Hub and Spoke (H\&S) ID have a conformation which sees the simultaneous presence of one or more large companies, that form the core of a system, geographically concentrated, also made up of many smaller companies. Given the asymmetry of power, the relationships that are established between firms are of vertical integration (with hub companies) and horizontal (with other companies). They can be shaped like a ring or a nucleus, according to the different kind of dependence that is generated between the businesses in the district.

Commercial dynamics between district businesses are based on long-term contracts and employee's management is often operated at the district level. This also implies the exchange of human resources between companies. However, inter-company HR exchanges concern only blue-collar and employee staffs, while company managers follow an intra-company management system.

\section{The internationalization of businesses [23-30]}

The term "internationalization" refers to the expansion of the company outside its national market. Actually, the internationalization of activities represents a fundamental way in which the company creates value, extends its competitive advantage, remunerates the resources invested, accesses new opportunities and resources for growth.

It is clearly a complex path that can't be underestimated: it is accompanied by a fundamental and often irreversible business transformation process, which involves financial aspects, organizational and technical structure, market positioning and human resources management. This process tends to create markets that transcend national boundaries, to the point of becoming international or, truly, "global". 
Globalization, therefore, is the process of growing integration of the economies of different areas of the world: it reduces and ultimately eliminates the limiting obstacles for the free movement of goods, services, capital, people and knowledge.

Companies have to deal with the world economy, as it provides market outlets, supply channels, knowledge, technology, resources and incentives needed for their business.

The approach to a foreign market involves many evaluations: in addition to the development prospects, it is necessary to consider the infrastructural and demographic conditions, the political, economic and cultural context, the tariff barriers and more. The development perspective is, therefore, the reason that pushes the manager to consider the hypothesis of an internationalization strategy, but it is not a sufficient condition for being able to pursue and complete this strategy.

Businesses must overcome information barriers higher than those present on the internal market. In order to develop an internationalization strategy, it is necessary to carry out in-depth studies of the target markets and to enter by playing according to the "house rules". It is important to use detailed planning to reduce risks. The planning process must be internal (through company controls) and external (market studies, business plans, marketing plans), in order to identify both the external positioning and the strategy.

The company that wants to internationalize must possess and offer unique and distinctive competitive advantages. Only in this way and going on according to defined rules, the goal will be reached.

Internationalization can be done by:

a) trade expansion: is to export and marketing abroad of goods produced in the country of origin;

b) Foreign Direct Investment (FDI): This covers an investment system, made by a foreign investor, through the holding of shares in a domestic company;

c) intermediate forms of internationalization: these are agreements, licenses, technical and commercial assistance contracts, etc., which make it possible to sell or rent the technology to local operators in foreign countries.

The main economic reasons that can push companies towards internationalization strategy can be traced to:

- find new business opportunities in a contracting market;

- avoid the price war;

- reduce risks by differentiating the markets;

- obtain faster and safer payments;

- stimulate new business ideas;

- reduce production and distribution costs.

Through internationalization, 4 strategic objectives can be achieved:

1. Development of new markets: every country is a market opportunity. For many companies it is necessary to enter markets that have a huge consumer base with a certain income, or to choose countries that can be "springboards" to enter new markets.

2. Access to local resources: such as low labor costs, technological skills, natural resources, raw materials, as in the case of Oil \& Gas companies.

3. Learning: some companies decide to enter certain markets to learn skills or knowledge, regardless of market conditions. 
4. Coordination of international activities: in order to decide which sector / market to enter, a risk / opportunity analysis must be carried out, because internationalization is not easily reversible.

The choice of the market/sector is influenced by:

- International strategic orientation. The company's competitive attitude is important: at the first entry into an international market, it will choose low-risk markets, similar to the domestic one, in terms of language, culture and more. If, on the other hand, the company is not at its first experience, it will have a greater risk appetite and it will look for markets other than the domestic one.

- Characteristics of the market and industry. It's necessary: to analyze the market potential, i.e. size and growth methods; obtain information, such as the degree of urbanization, climatic conditions and prevailing lifestyles; analyze market demand and its elasticity.

- Nature of the competitive environment. It depends on the structure of the sector and the strategies adopted by competitors. It is necessary to know the degree of concentration, the allocation of resources in the destination country, the presence of raw materials, the quality and cost of human resources and infrastructures.

The industry characteristics affect the company's conduct and its performance.

\section{The SMAPE Ltd $^{2}$}

\subsection{History: notes}

The SMAPE Ltd. - Southern Society for Petroleum and Ecological Applications - is an Italian, privately owned partnership that operates as an international service provider in the Oil \& Gas sector.

The company was founded in 1989 in Abruzzo, in the province of Pescara, by its founder, Stefano Bianchi, a former entrepreneur in the oilfield.

It is a family business whose ownership structure does not provide for the presence of a single family, but the union of three partners, owners of different amounts of capital: the Bianchi family, majority shareholder, and minority shareholders Rossi and Gialli.

The three founders, in 1975, had created another company, also a family business, with the same percentage split of the shares, the Italfluid Geoenergy (ITF), based in Notaresco, in the province of Teramo, which operated in profitable way. The ITF "group" in 1989, was formed by the companies:

- ITF Sefim, holding company of the Bianchi family, with real estate assets and shares in Geoenergy;

- ITF Geoenergy Ltd., the primary operating company;

- ITF Cosmep Ltd, a "wild card" company that, over the years, was used for different operating purposes;

- PTS - Petroservices Mediterranea Ltd - owned by Smape and a Sicilian partner.

\footnotetext{
${ }^{2}$ We thank the sole director and the top management for their willingness to provide sensitive data and information concerning the company activity, regarding the internationalization strategies and the development of activity in foreign markets. The names of the members and others do not correspond to reality.
} 
So, in 1989, driven by years of experience in the sector and taking advantage of the tax policy for investments in Southern Italy, the three partners created this new company (based in another province, Pescara) to develop special systems for the treatment of the hydrocarbons produced from wells, such as desulfurization.

The company was born with the presence of only two people: over the years it has had a staff of over 250 people, divided between Italy and abroad.

In the first years of operation, Smape built and managed a desulphurization plant used at the ENI well in Villafortuna, in the Ticino Park.

In 1990, the group began to take an interest in the "Coiled Tubing" (CT) activities carried out in Italy by the multinationals Nowsco, Dowell-Schlumberger, Halliburton, BJ - Byron Jackson and SIAT of Ravenna. In 1991, when Nowsco left the market and purchased some CT equipment, the company began developing the CT service.

In 1992, this service was further developed: four specific people were dedicated to its growth and implementation, Verde, as head of development; Nero, a Nowsco employee, as an "expert" in the sector; Blu and Arancio, seconded by ITF Geoenergy.

For most of its existence, Smape has operated in a close and connected way, often synergistically, with the "mother company" ITF Geoenergy: born as one of its branches, with specific attitudes and services complementary to those of the ITF, it is currently a completely independent company. In its field, Smape has shown great potential and capacity for growth, both for the experience it possesses and for its ability to innovate (with new equipment and new ways of using existing equipment). The first "innovative" operation was in 1992: the mining closure of the Guglionesi 5 well, carried out with the use of the 1-inch CT for pumping the cement. This type of application, never carried out before, will be resumed during the year and still today constitutes a valid and economical alternative to the closure of mining wells carried out in a classic way, with a work-over system. Subsequently, the company establishes working relationships with Agip (today ENI), incoming in their vendor list. After a year, 19 operations were carried out, including eight mine closures, and the use of new equipment was developed and tested (a 2-inch CT, complementing the "cheap" gas wells). The introduction of this format in Italy was absolutely innovative, to the point of making it necessary to purchase new equipment suitable for handling this tube. In 1995 the transactions carried out rose to 47. In addition, off-shore operations were intensified, reserved for the most reliable contractors, reflecting the greater experience and quality of the service offered.

In 1996 Smape, in collaboration with Transocean, carried out three CT drilling operations on behalf of ENI: a 27/8-inch TC was introduced. For this circumstance, Smape has developed an adaptation to the tower of an equipment (MS50), in order to adapt to the shaft for lifting and moving the injector used for drilling.

In 1997, the company recruits five new experienced employees, the number of works carried out in the open sea increases significantly and 75 operations are carried out.

In 1998-1999, during the first crisis in the O\&G sector, the company still manages to stabilize its business and to promote the use of downhole tools for countless new applications. In 2000 Smape also started operating in the oil wells of Val d'Agri, introducing the new 13/4-inch CT and performing some innovative permanent "Velocity String" installations, always using CT. In 2002 the number of operations carried out rose to 170 ; in 2003, 300 operations were carried out in one year. 


\subsection{Core business and services}

The company's goal is to provide specialized services in oilfields around the world, in compliance with the best practices, standards, quality, safety and environmental requirements recognized by the industry.

Provides the following service lines:

1. Coiled Tubing: the company has the largest fleet in Southern Europe of complete equipment for Coiled Tubing services, with units suitable for both on-shore and offshore applications and for operations in sensitive areas for low noise and exhaust emissions. Dedicated engineering teams are involved in the initial design preparation, planning and simulation of the job. Technical chargeback is provided through engineering analysis and post-work reporting, to provide a continuous improvement process.

2. Nitrogen: The company offers a complete nitrogen pumping service (for on-shore and off-shore applications), starting from the initial design of the work up to the execution and analysis phases of the work. All nitrogen processes are supported by experienced teams of technicians and field personnel.

3. Pumping and Stimulation: Fluid pumping equipment includes pumping units specially designed for high speed / high pressure applications and are available for use in conjunction with CT operations. The engineering teams are available from the initial preparation of the design of the pumping stimulation service, to the supply of dedicated equipment and specialized personnel, able to meet the different technical needs which have their origins in the different markets and applications.

4. CT Downhole Tools (TT): the work-over operations are used to maintain the initial levels of productivity and efficiency. Smape has developed a wide range of tools for the drainage of passing pipes, positioning itself among the leaders in the provision of $\mathrm{CT}$ and TT services.

5. Pipeline-Service: the Pipeline-Service division covers a wide range of applications, both in the upstream sectors and in the oil and gas sector.

6. Chemical Injection: this division operates to provide injection services, performed with polymer gels EOR (Enhanced Oil Recovery).

\subsection{The ownership structure and management}

Smape Ltd. is a family-owned SME: it belongs to the extended family business type, joint venture, family and non-family, with the control package in the hands of the family that created the business. The family also holds key positions in the management and direction of the company. The company has already achieved a generational expansion: it is directed by a Sole Director, dr. A. Verde, who has managed it since its beginning. Compared to the Bianchi family, Dr. Verde is the sonin-law of prof. S. Bianchi, who, despite being its founder, has never interfered in operational management and has never held any role in the company organization chart. The second generation is already present, at various operational levels: two of the three children of Dr. Verde, Marco and Lucio, have already been introduced into the company, but only one, the primogenital, holds important roles in the company (management of foreign activities). The second, just graduated, is at the beginning of his training and does not yet appear in the organization charts of the company. The company, which has always been managed in a modern and managerial way, has received new life and new impulses from the co-optation of external managers and the 
entry of close family members into the company. The new generation has undergone a long training, like any other employee, with the aim of being hardened for the job, understanding the reference markets, gaining experience in the field, in order to create their own know-how. This management strategy, both of the company and of the family, has been successful, as well as profoundly different from the one prof. Bianchi, former CEO of ITF Geoenergy Ltd., has adopted into his group.

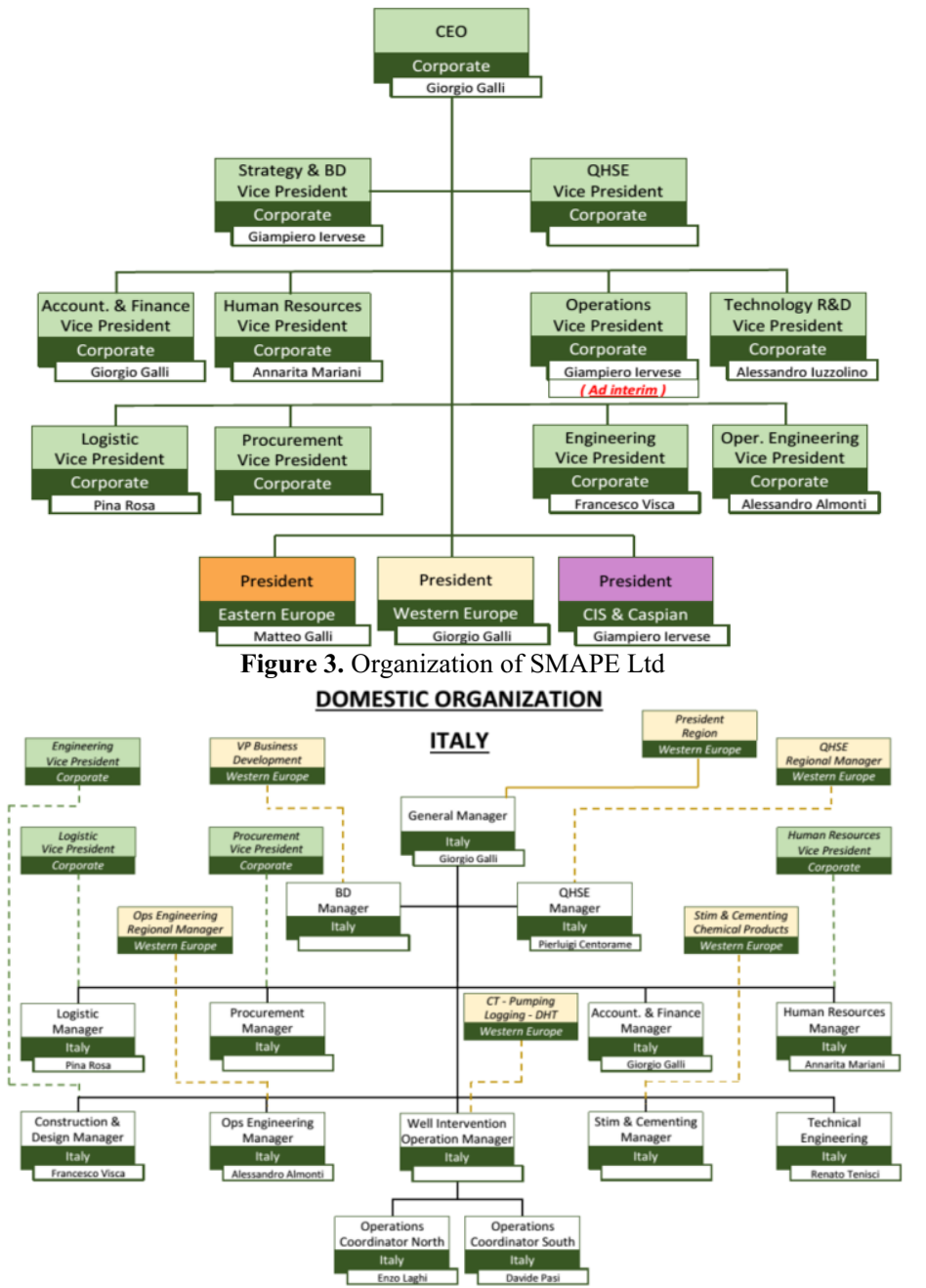

Figure 4. Domestic Organization: Italy.

Table 3. The increase of employees

\begin{tabular}{|c|c|c|c|c|c|c|c|}
\hline YEAR & \multicolumn{7}{|c|}{ EMPLOYEES } \\
\hline & TOTAL & ITALY & EGT & ALB & AZB & ROM & KAZ \\
\hline 1989 & 2 & 2 & 0 & 0 & 0 & 0 & 0 \\
\hline 1990 & 2 & 2 & 0 & 0 & 0 & 0 & 0 \\
\hline 1991 & 2 & 2 & 0 & 0 & 0 & 0 & 0 \\
\hline 1992 & 2 & 2 & 0 & 0 & 0 & 0 & 0 \\
\hline 1993 & 2 & 2 & 0 & 0 & 0 & 0 & 0 \\
\hline 1994 & 4 & 4 & 0 & 0 & 0 & 0 & 0 \\
\hline 1995 & 8 & 8 & 0 & 0 & 0 & 0 & 0 \\
\hline 1996 & 12 & 12 & 0 & 0 & 0 & 0 & 0 \\
\hline
\end{tabular}




\begin{tabular}{|l|c|c|c|c|c|c|c|}
\hline 1997 & 18 & 18 & 0 & 0 & 0 & 0 & 0 \\
\hline 1998 & 19 & 19 & 0 & 0 & 0 & 0 & 0 \\
\hline 1999 & 19 & 19 & 0 & 0 & 0 & 0 & 0 \\
\hline 2000 & 19 & 19 & 0 & 0 & 0 & 0 & 0 \\
\hline 2001 & 20 & 20 & 0 & 0 & 0 & 0 & 0 \\
\hline 2002 & 22 & 22 & 0 & 0 & 0 & 0 & 0 \\
\hline 2003 & 27 & 27 & 0 & 0 & 0 & 0 & 0 \\
\hline 2004 & 31 & 31 & 0 & 0 & 0 & 0 & 0 \\
\hline 2005 & 33 & 33 & 0 & 0 & 0 & 0 & 0 \\
\hline 2006 & 39 & 39 & 0 & 0 & 0 & 0 & 0 \\
\hline 2007 & 49 & 49 & 0 & 0 & 0 & 0 & 0 \\
\hline 2008 & 82 & 55 & 27 & 0 & 0 & 0 & 0 \\
\hline 2009 & 99 & 61 & 38 & 0 & 0 & 0 & 0 \\
\hline 2010 & 123 & 65 & 58 & 0 & 0 & 0 & 0 \\
\hline 2011 & 148 & 82 & 66 & 0 & 0 & 0 & 0 \\
\hline 2012 & 171 & 103 & 48 & 18 & 2 & 0 & 0 \\
\hline 2013 & 191 & 119 & 47 & 22 & 3 & 0 & 0 \\
\hline 2014 & 226 & 136 & 41 & 26 & 3 & 0 & 0 \\
\hline 2015 & 215 & 139 & 41 & 12 & 3 & 0 & 0 \\
\hline 2016 & 235 & 120 & 99 & 7 & 3 & 6 & 0 \\
\hline 2017 & 207 & 114 & 67 & 7 & 4 & 15 & 0 \\
\hline 2018 & 223 & 115 & 58 & 22 & 4 & 23 & 1 \\
\hline
\end{tabular}

Today, the ITF and Smape Ltd are not only two fully independent companies, but often operate as competitors. This radical change in relations between the two groups was caused by the generational change that took place in ITF in the last five years: this turnover, inadequately managed by both the founder and his successors, caused a break in the family system. The management strategy of ITF, in fact, was of a totalitarian nature: having created his "empire" from nothing and perceiving the company as part of himself, the founder has always kept all the power and decision-making in his own hands. From the point of view of ITF management, prof. Bianchi gave his two partners a fair amount of autonomy. The involvement of family members, especially daughters and daughters' in-laws, proved to be completely marginal. The definition of roles and of the delegation system within the company, even if theoretically existing, has not actually been implemented.

In fact, when the company and Professor Bianchi found themselves in front of the natural moment of the generational change, a myopic vision appeared in the eyes of the founder: this, combined with various family vicissitudes, led inexorably to a clear and inevitable corporate split [31].

This split did not concern Smape, which in any case already constituted an independent company from the ITF, but all the companies that made up the group. In the Smape management, instead, as in all multinational companies, managerial conduct provides not only a division and separation of roles for specific skills and knowledge, but also a remuneration system linked to results [32]. In this way, the motivation of the personnel, especially at managerial levels, is stimulated on to continuous improvement, in order to achieve ever higher performance levels. Regarding the management of personnel, different contractual situations are applied in the company, depending on the country of destination and allocation of the employee considered. In fact, for Italy both permanent contracts and fixed-term contracts are applied, governed by Italian legislation and the national contract of the sector.

As regards work contracts for foreign personnel, we can distinguish different cases: foreign staff is employed at the local office, with stipulated fixed-term contracts, with a contract provided for by local regulations. Furthermore, in the management of human 
resources, the exchange of human resources between the various operational areas is often used, with the exception of the Schengen area, which is difficult to access for non-EU personnel. In some rare cases, some specific human resources, or sector specialists, have been hired under an "international" contract, as consultants. Finally, as regards the treatment of Italian personnel abroad, it takes the form of a "travel" regime: if the stay abroad is, cumulatively, 183 days a year, the "secondment "of the foreign employee.

Another fundamental resource, never underestimated in the company, is represented by innovation. Smape has always pursued the search for new ways of operating and exploiting technology (as for $\mathrm{CT}$ ), to become one of the fastest growing segments in the oil services sector. This growth is supported by continuous technological advances and the use of CT to be able to perform an ever-growing list of field operations. An element that has played in favor of this development, in my opinion, lies in the multidisciplinarity and in the possession, which exists in the company, with a wealth of very different basic knowledge. The company, in fact, since its establishment and continuing with the co-optation of people of different educational backgrounds, includes engineers, both mining and chemists, economists, geologists, pure chemists, etc., who have been able to put together and compare their knowledge. All this, as our KM studies teach us, has led to a multiplicity of points of view, which has allowed us to broaden the physical and mental horizons of the company itself.

\subsection{Development and internationalization ${ }^{3}$}

Like many companies operating in the oil sector, Smape links its destiny to the oil market, the Oil \& Gas economy and the exploitation of underground resources. The company is beginning to feel the need of expanding its boundaries. The first step abroad was in 2004, when the first operations were carried out in Croatia for INAAGIP: however, beyond the foreign customer, this experience did not constitute a particular innovation, because they were carried out in the Adriatic off-shore, often with Italian starting point. The real international test took place in Algeria, for the AIFG group: even in this case, despite a good performance, the operations were wild shortly after, because the company had no direct interest in their development. However, thanks to these, Smape has realized that it has an interest in expanding abroad and internationalizing its business. In fact, in 2007 the ITF Egypt LLC was created in the Free Zone of Suez. The partners are 43\% Smape and the same subjects of ITF Geoenergy and Smape for the rest. The original purpose of the company is to bring all the group's services to the country. In 2008, however, the second "crisis" of the oil price occurred, with the consequent decrease in work volumes and turnover: thus, the Egyptian company was left on stand-by and Smape broadened its range of action in across the EU. The first works are carried out in Greece, then in Spain and Germany. In the years 2010/12, a collaboration started with the multinational TIORCO-Nalco for the exclusive worldwide pumping of special products in oil wells. Thus, he finds himself working in several foreign countries, including Azerbaijan, Russia, Congo, Equatorial Guinea. With the oil price crisis that started in 2014, the company chose a strategy of "conservation" of human capital, limiting itself to optimizing all costs and giving up all fixed-term relationships. In any case, the company still continues to work

${ }^{3}$ Despite having specific and detailed data, it was decided to provide only aggregated data and values, as the company is in full operation and we do not want to disclose sensitive data, for competitive reasons. 
for the development of new foreign markets: a lot of time and resources are used in this sense. On 6/12/2017 Smape Kazakhstan JV has been established in Almaty, with partners Smape Ltd at 70\% and Kazburgas LLP at 30\%, whose corporate purpose is the execution of the "high level CT" contract for Karachaganak Petroleum Operating Co.to Aksai. On 20/12/2017 the Smape Ltd. branch in Kazakhstan has been registered in Almaty.

Table 4. Corporate forms established in foreign countries

\begin{tabular}{|c|c|c|c|c|}
\hline COUNTRY & COMPANY & FORM & TAXATION & YEAR \\
\hline Egypt & Italfluid Egypt & LLC $($ srl $)$ & Free Zone & 2007 \\
\hline Albania & Smape & Sh.p.k $($ srl $)$ & Ordinary & 2011 \\
\hline Azerbaijan & Smape & Branch & Ordinary & 2011 \\
\hline Romania & Smape & Branch & Ordinary & 2016 \\
\hline Serbia & Smape & Branch & Ordinary & 2016 \\
\hline Kazakhstan & Smape & Branch & Ordinary & 2017 \\
\hline Kazakhstan & Smape JV & LLP $($ srl $)$ & Ordinary & 2017 \\
\hline
\end{tabular}

The choice of the corporate form has undergone an "evolution" over time: the first foreign company was under local law with the participation of the Italian company (30$40 \%$ ) and the direct participation of private individuals for the remainder.

In Albania, the choice fell on LTD with a single shareholder, Smape Ltd., for legal issues relating to the direct liability of Smape Ltd. and for the need to protect the latter in countries characterized by low legal certainty. Therefore, to encourage a correct tax structure (according to the principles of the OECD and Italian taxation), to encourage the transfer of assets from the Italian body to the foreign one and vice versa, and to "consolidate" foreign companies in the Smape Ltd. financial statements, the solution chosen was to establish branches, both with and without legal personality, depending on the country considered. An exception was made for Smape Kazakhstan LLP, which is a JV with a local partner, as requested by the host country and by the client.

However, Smape's foreign works have gone further. There are many activities carried out in other states and with various oil companies, taking the existing foreign offices as an organizational basis and employees.

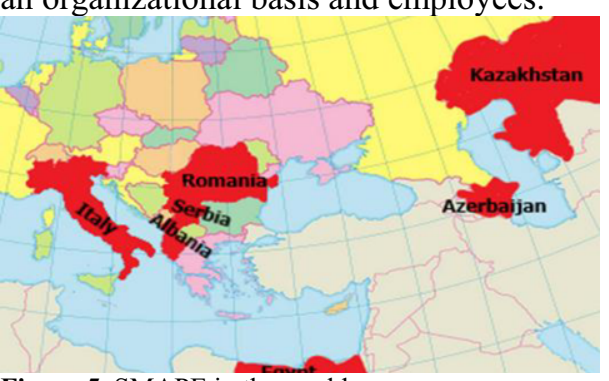

Figure 5. SMAPE in the world.

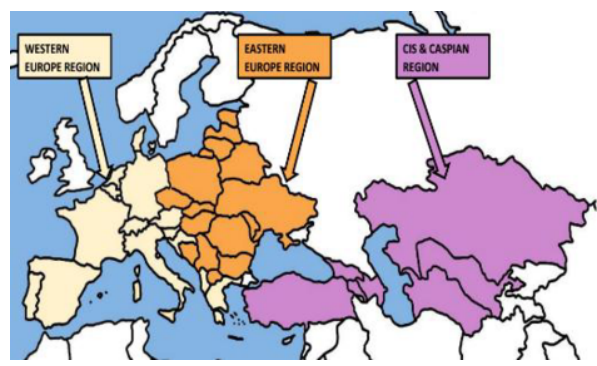

Figure 6. Geomarket division.

The geographical areas identified above, indicate the areas of operation, independently from the specific foreign offices, of which single and detailed data will not be provided in his discussion. The organization for operational areas has been designed as indicated in the following organization charts. 


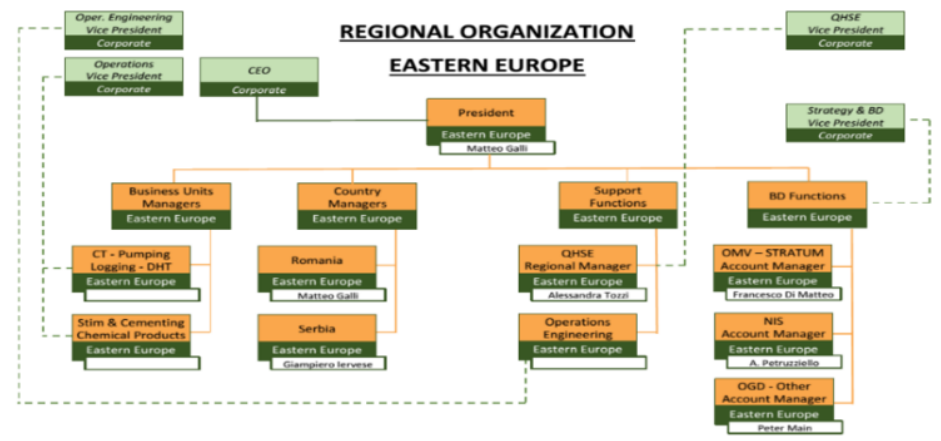

Figure 7. Regional Organization Eastern Europe.

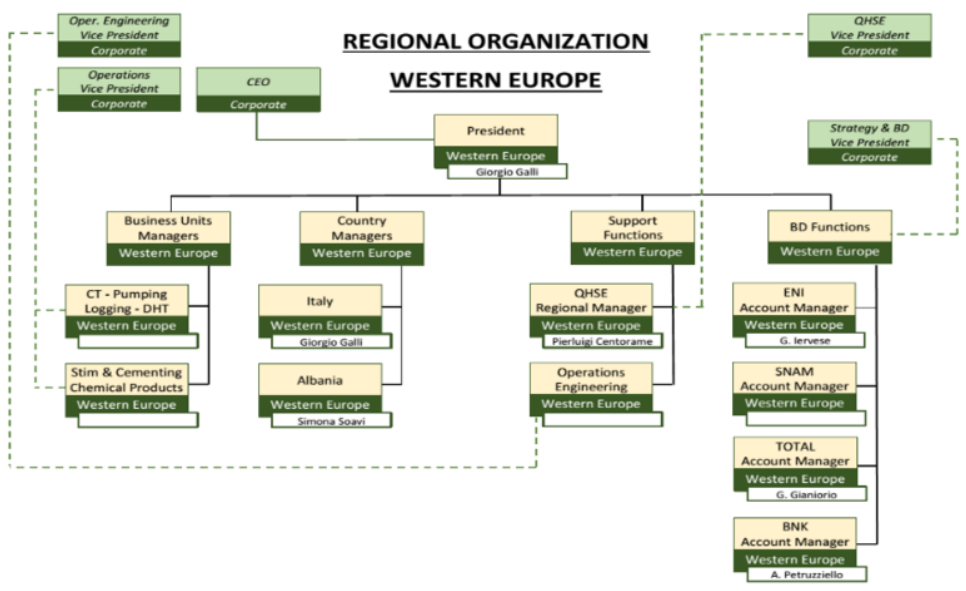

Figure 8. Regional Organization Western Europe.

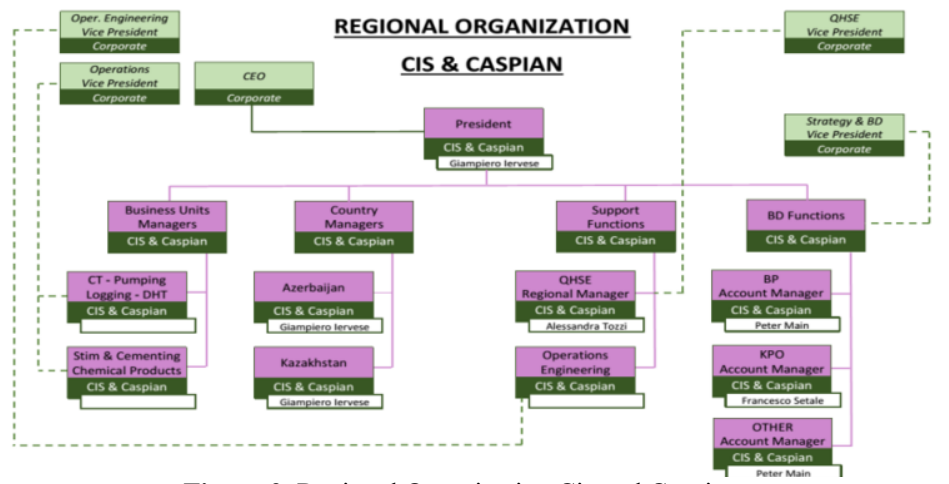

Figure 9. Regional Organization Cis and Caspian.

In previous organizational charts, the lines represent the type of relationship existing between the different company figure: Dotted Line, means understanding the presence of a double relation to the general guidelines of the company; Solid line, is intended as the main report for the daily and weekly assignments, annual activities and the direct management. 
Some of the organizational charts are currently subject to revisions, as regards the assignment of roles and activities.

Table 5. Global function Summary

\begin{tabular}{|c|c|}
\hline $\begin{array}{l}\text { CHIEF EXECUTIVE } \\
\text { OFFICER: }\end{array}$ & $\begin{array}{l}\text { is responsible of making major corporate decisions for Company's long-term strategy } \\
\text { with a view to creating shareholder value. }\end{array}$ \\
\hline $\begin{array}{l}\text { VICE PRESIDENT } \\
\text { STRATEGY AND BUSINESS } \\
\text { DEVELOPMENT: }\end{array}$ & $\begin{array}{l}\text { is responsible of the development and execute the Company market development } \\
\text { strategy globally. }\end{array}$ \\
\hline VICE PRESIDENT QHSE: & $\begin{array}{l}\text { is responsible of issuing global policies and guidelines to Regional QHSE departments } \\
\text { and of the continuous monitoring, auditing and verification of the compliance of local } \\
\text { and national systems to the corporate guidelines and to national laws and regulations. }\end{array}$ \\
\hline $\begin{array}{l}\text { VICE PRESIDENT } \\
\text { ENGINEERING: }\end{array}$ & $\begin{array}{l}\text { is responsible for all the new equipment design, construction and heavy maintenance to } \\
\text { support the global activities. Is responsible of issuing the global policies and guidelines } \\
\text { related to engineering and construction. }\end{array}$ \\
\hline $\begin{array}{l}\text { VICE PRESIDENT } \\
\text { ACCOUNTING \& FINANCE: }\end{array}$ & $\begin{array}{l}\text { is responsible for managing the global financial matters of the Company, including } \\
\text { international transaction policies of the company, compliance to international } \\
\text { regulations. }\end{array}$ \\
\hline $\begin{array}{l}\text { VICE PRESIDENT HUMAN } \\
\text { RESOURCES: }\end{array}$ & $\begin{array}{l}\text { is responsible of global human resources management and of issuing policies and } \\
\text { guidelines to local and national departments; manages international rotations and } \\
\text { relocations. }\end{array}$ \\
\hline $\begin{array}{l}\text { VICE PRESIDENT } \\
\text { OPERATIONS: }\end{array}$ & $\begin{array}{l}\text { is responsible of the global operation planning and execution in compliance with the } \\
\text { global policies and guidelines; is responsible of the management of mobile assets and } \\
\text { equipment dedicated to operations, of the optimization of corporate material resources, } \\
\text { of the data gathering and reporting on operation execution and economy. }\end{array}$ \\
\hline $\begin{array}{l}\text { VICE PRESIDENT } \\
\text { OPERATIONS } \\
\text { ENGINEERING: }\end{array}$ & $\begin{array}{l}\text { is responsible of the global operation-oriented engineering, of the issue of all company's } \\
\text { technical documents related to operations, of the issue of global policies and guidelines } \\
\text { related to operative engineering. }\end{array}$ \\
\hline $\begin{array}{l}\text { VICE PRESIDENT } \\
\text { TECHNOLOGY AND R\&D: }\end{array}$ & is responsible for all the new technology development to support the global activities. \\
\hline $\begin{array}{l}\text { PRESIDENT ESTEARN } \\
\text { EUROPE REGION: }\end{array}$ & is responsible for the management and results of the region. \\
\hline $\begin{array}{l}\text { PRESIDENT WESTERN } \\
\text { EUROPE REGION: }\end{array}$ & is responsible for the management and results of the region. \\
\hline $\begin{array}{l}\text { PRESIDENT CIS AND } \\
\text { CASPIAN REGION: }\end{array}$ & is responsible for the management and results of the region. \\
\hline VICE PRESIDENT LOGISTIC: & $\begin{array}{l}\text { is responsible of management and planning logistic activity globally and in compliance } \\
\text { with the global policies and guideline. }\end{array}$ \\
\hline $\begin{array}{l}\text { VICE PRESIDENT } \\
\text { PROCUREMENT: }\end{array}$ & $\begin{array}{l}\text { is responsible of management and planning procurement activity globally and in } \\
\text { compliance with the global policies and guideline. }\end{array}$ \\
\hline
\end{tabular}

\subsection{Internationalization strategies considered and implemented}

The oilfield internationalization strategy follows three main guidelines: firstly, it is necessary to go abroad to follow the exploitation of a natural resource, which is not present in all territories and which, in Italy, is present to a limited extent; secondly, internationalization is implemented to expand markets for business; not least, companies that work for Oil Companies often have to follow the hub company in the countries where it operates. This happens because often the oil system (national and international) is constituted in district form (H\&S district). The strategy followed by Smape was conducted autonomously, that is, in an absolutely independent way and unrelated to the internationalization and development policies implemented by the Italian government.

The factors that outline the company's internationalization strategy are:

- evaluation of the necessity for internationalization, as a factor for the development and stability of the company;

- market analysis with consideration and evaluation of the following factors: 
a) Logistics: choice of geographically not too distant markets, in order to easily transfer human and material resources already used in Italy;

b) Political and cultural: operating simultaneously in different countries, but similar to us, would have made it "easier" to deal with this situation, especially for the workforce.

c) Competition: do not try to enter markets where there is strong competition, such as those of the North Sea districts;

- risk analysis: socio-political, economic;

- market analysis: market value, presence and strength of competitors, cost / benefit ratio;

- technical analysis: services requested in $O \& G$, opportunities for the services offered by Smape, technical standards required;

- legal analysis: consider the existing laws, regulations and legal constraints of the countries in which we want to internationalize, in order to evaluate the opportunity and the concrete possibility of being able to enter the new market, investment protection;

- economic analysis: taxation, degree of market liberality, possibility of repayment of capital, customer solvency.

From the analysis of the aforementioned factors it emerged, for example, that the East-Europe-Caspian geographical area is the one that collects the highest score in the evaluations, and it is exactly the strategy that Smape is implementing.

Egypt, on the other hand, which has met most of the requirements considered, has shown a low propensity to reward the quality of the service offered and the presence of local competitors not of the same level, but extremely cheap. However, this assessment, which did not emerge in the preliminary phase, conditioned the local development of the company to the point of blocking it; to date, the country is considered attractive for other types of activities (e.g. EPF or similar projects), but not for those offered by Smape. In the future, Smape could consider, for further growth and evolution, objectives different from those considered so far. Naturally, the strategic analysis of the choice to internationalize in a particular country is made in relation to the specific moment in which one operates: tomorrow, some considerations may no longer be valid.

Here is an example of selecting an international market:

1. We start by excluding countries that are not doing well, for strategic reasons or for lack of interest;

2. Among those that remain, we consider those in which we consider particular difficulties of penetration and / or too many risks of various kinds, mainly public and political order;

3. Among those that remain, the choice may be the consequence of very different elements and events, both occasional and systematic, such as, for example, the randomness of a contract or a single job.

4. For the other markets, a comparison is made between the respective cost / benefit analyzes carried out.

5. Parallel to the above, the positions of the competitors are analyzed to verify where there are greater (and fruitless) probabilities of confrontation and where, on the contrary, a more peaceful penetration is possible.

Not all competitors are the same. Smape, due to its structure and its skills, is often faced with companies that are superior in order of magnitude: in this case it is not uncommon for the interests to be different. It has to be considered, however, that entrepreneurial activity, like all economic activities, is subject to a part of risk and the choice made is not always the best, not leading to the desired and planned results. In the case of Egypt, e.g., an in-depth analysis was carried out by searching for specific 
data on the Oil\&Gas market and building a dedicated business plan. Not for this, however, the real result turned out to be in line with expectations and with the plan forecasts.

\subsection{Some economic performance of internationalization.}

Going beyond the purely strategic point of view, to understand and appreciate the development that Smape has been able to pursue, to make an economic assessment of how the company's activity has evolved and grown, from its creation to today, just take a look at the numbers. If you look at the following two graphs, of which the second is simply the highlighting of the economic results of the company, when it was still operating mainly in the national context, you can easily see how the implementation of internationalization strategies constituted, for Smape, a development booster. The graphs below, however, show the development, from an economic and revenue point of view, the company in the international arena. As previously mentioned, the tables and the specific numbers are not reported, for privacy reasons.

Graphic 1. Smape global sales and profits in Euro 1995-2018 Graphic 2. Total Revenue 2007-2018
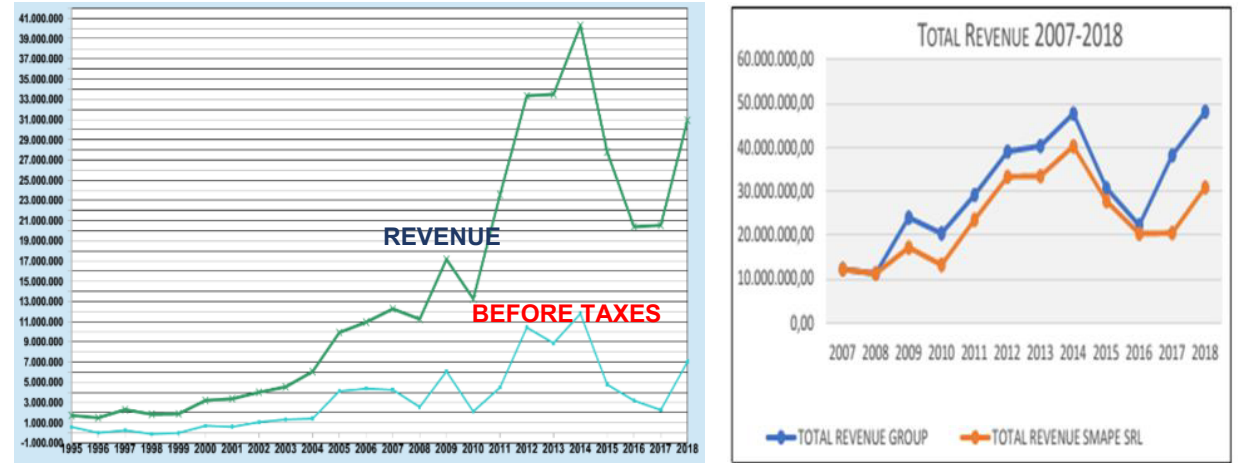

Graphic 3. Smape global sales and profits in Euro 1995-2007 Graphic 4. Total EBIT 2007-2018
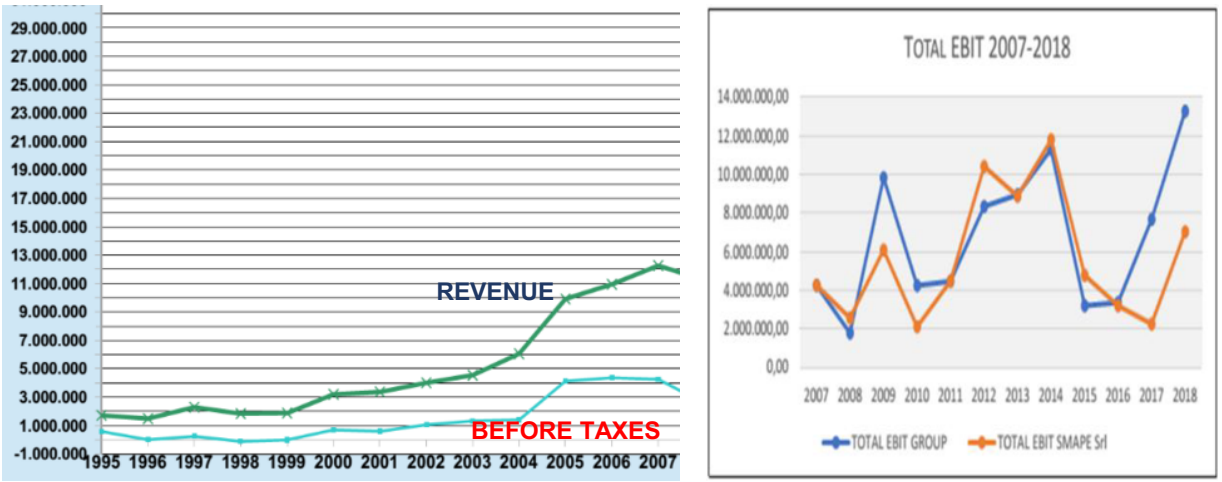

The graphs, concerning the economic results achieved by the company over the years, show a significant increase in revenue (Graphic 2 and 4). International development, despite having led to huge investments, have given a great boost to corporate activity. Certainly, with the start of the implementation of internationalization strategies, the company has shown a more fluctuating economic 
trend, characterized by high peaks of activity, both very positive and lower (Graphic 1 and 3). In any case, there has never been any real economic losses, but rather a settling of the activity in unfamiliar and highly competitive markets. The years when there was no activity growth correspond, essentially, to periods of global Oil \& Gas crisis. Despite this, the Smape has managed to maintain an adequate economic result. In this way, through effective and efficient management of internationalization strategy, the company has established itself in foreign markets in a competitive way.

\section{Conclusions.}

In a global universe, where there are no longer borders between countries, limited information, difficulties in accessing technology and explicit knowledge, the entrepreneurial and strategic choice to internationalize has increasingly become an "obligation" for entrepreneurs. The increase in competition and the limited barriers to entry into the market can no longer guarantee small and medium-sized enterprises to live, and not survive, only by operating in their national reference market. Even family businesses, generally characterized by small to medium size, are not protected from globalization and the risks of competition. In the Italian business structure, SMEs and family businesses are the backbone of the economy: our companies have always been medium to small in size and have served as supporters and subcontractors of services to larger companies, or have joined the district systems to be able and possess the necessary skills for the production of finished products.

However, there are exceptions: the Smape Ltd case proves it.

The company, which was absolutely small and essentially family at its inception, has grown. Born thirty years ago, with an initial investment of 500,000 euros discounted, Smape has been able to grow and develop constantly. It represents a case of excellent SME and family business: the family business was addressed according to managerial methods, abandoning the classic organizational and managerial paradigms, characteristic of its type of business. The management has been stimulated to continuous improvement and the company has become a multinational, able to compete with business categories of all sizes and occupying market segments, often "reserved" for much larger companies.

The combination of two key factors has led it to become the market leader in the TA and auxiliary services sector: first, dimensional flexibility, considering that Smape is a medium-sized company, which has allowed it to bear operating costs "content"; second, the managerial vision of a large company.

After thirty years the company has about 250 employees, a managerial organization, seven foreign offices / companies, depending on the types adopted in the different countries and dictated by specific regulations, and a global sale of about 40 million euros per year.

\section{References}

[1] Marshall A., The economy of Industry, London: Macmillan Press, 1879.

[2] Markusen A., "Sticky places in Slippery Space. A typology of Industrial districts", Economic Geography, Vol. 72, Issue 3, pp.293-313,1996.

[3] Testa G., "Knowledge transfer in vertical relationship. The case study of Val D'Agri oil district.", Journal of Knowledge Management, Vol.17, n.4, pp.617-636, 2013. 
[4] Astrachan J.H., Shanker M.C., "Family Businesses' contribution to the US economy: a closer look", Family Business Review, Vol.16, Issue 3, pp. 211-219, 2003.

[5] Chua J.H, Chrisman J.J., Sharma P., "Defining the Family Business by Behavior", Entrepreneurship Theory and Practice, Vol.23, Issue 4, pp. 19-39, 1999.

[6] Klein S.B, Astrachan J.H., Smyrnios K.X., "The F-PEC Scale of Family Influence: Construction, Validation, and Further Implication for Theory, Entrepreneurship Theory and Practice, Vol.29, Issue 3, pp. 321-339, 2005.

[7] Sharma P., Nordqvist M., "A Classification Scheme for Family Firms: From Family Values to Effective Governance to Firm Performance," in Family Values and Value Creation: How Do FamilyOwned Businesses Foster Enduring Values. Eds. J. Tapies and J. L. Ward. New York: Palgrave Macmillan Publishers, pp.71-101, 2008.

[8] Arregle J. L., Hitt M. A., Mari, I. A missing link in family firms' internationalization research: Family structures. Journal of International Business Studies, 50(5), 809-825, 2019.

[9] Shanker M., Astrachan, J., "Myths and realities: family businesses' contribution to the US economy, a framework for assessing family business statistics", Family Business Review, 9(2), 107-119, 1996.

[10] Demattè C., Corbetta G., "I processi di transizione delle imprese familiari", Working Paper, Università Commerciale L. Bocconi, Milano, n.53/22, pp.10 ff, 1993.

[11] Corbetta G., Le imprese familiari: caratteri originali, varietà e condizioni di sviluppo, EGEA, Milano, 1995; Corbetta G., "Patterns of Development of Family Businesses in Italy", Family Business Review, Vol.8, Issue 4, pp. 255-265, 1995.

[12] Becattini G., "Dal settore industriale al distretto industriale. Alcune considerazioni sull'unità d'indagine dell'economia industriale", Rivista di Economia e Politica Industriale, pp.1:7-21, 1979.

[13] Becattini G., "Riflessione sul distretto industriale marshalliano come concetto socio-economico", Stato e Mercato, n. 25, pp.114-115, 1989.

[14] Becattini G., Mercato e Forze Locali, Bologna: Il Mulino, 1987.

[15] Bellandi M, Russo M., Distretti Industriali e Cambiamento Economico Locale, Torino: Rosenberg \& Sellier, 1994.

[16] Becattini G., "Dal settore industriale al distretto industriale. Alcune considerazioni sull'unità d'indagine dell'economia industriale", Rivista di Economia e Politica Industriale, pp.1:7-21, 1979.

[17] Martiri P., Sui Rapporti tra Imprese in Un'economia Industriale Moderna, Milano: FrancoAngeli, 1980.

[18] Ottati D., "Trust, interlinking transactions and credit in the industrial district", Cambridge Journal of Economics, Vol.18, Issue 6, pp.529-546, 1994.

[19] Mistri M., Il Distretto Industriale Marshalliano tra Cognizione e Istituzioni. Roma: Carocci, 2006.

[20] Ottati D., Il mercato comunitario, In: Becattini G, editor. Mercato e Forze Locali: Il Distretto Industriale. Bologna: Il Mulino, 1987.

[21] Markusen J.R., Maskus K.E., "Discriminating among Alternative Theories of the Multinational Enterprise", NBER Working Paper No.7164, 1999a, Washington D.C.

[22] Markusen J.R., Maskus K.E., "Multinational Firms: Reconciling Theory and Evidence", NBER Working paper No.7163, 1999b, Washington D.C.

[23] Hymer S. H., "The International Operations of National Firms: A Study of Direct Foreign Investment". PhD Dissertation (1960). Published posthumously. The MIT Press, 1976. Cambridge, Mass.

[24] Vernon R., "International Investment and International Trade in the Product Cycle", The Quarterly Journal of Economics, Vol.80, Issue 2, May 1966, pp.190-207, 1966.

[25] Williamson O., "Transaction Cost Economics: The Governance of Contractual Relations", Journal of Law and Economics, n.22, pp.233-261, 1979.

[26] Madsen T.K., Servais P., "The internationalization of Born Globals: An evolutionary process?", International Business Review, Vol.6, n.6, pp.561-583, 1997.

[27] Mitchell J., Oil and gas reserves., Oxford Institute for Energy Studies/Chatham House, Oxford, 2004.

[28] Nanut V., Compagno C., Strutture organizzative e processi gestionali nelle piccole imprese: il caso del Friuli-Venezia Giulia, Milano: FrancoAngeli, 1989.

[29] Pukall T.J., Calabrò A., "The Internationalization of Family Firms: A Critical Review and Integrative Model”, Family Business Review, Vol.27, n.2, pp.103-125, 2014.

[30] Ratten V., Ramadani V., Dana L.P., Hoy F., Ferreira J., "Family entrepreneurship and internationalization strategies", Review of International Business and Strategy, Vol.27, n.2, pp.150-160, 2017.

[31] Ray S., Mondal A., Ramachandran K., How does family involvement affect a firm's internationalization? An investigation of Indian family firms. Global Strategy Journal, 8(1), 73-105, 2018.

[32] Ramón-Llorens M. C., García-Meca E., Duréndez A., Influence of CEO characteristics in family firm's internationalization. International Business Review, 26(4), 786-799, 2017. 